Sains Malaysiana 49(6)(2020): 1359-1370

http://dx.doi.org/10.17576/jsm-2020-4906-14

\title{
Zerumbone Induces Cytotoxicity and Inhibits Cell Migration of Human Colon Cancer Cells
}

(Zerumbon Mengaruh Kesitotoksikan dan Merencat Penghijrahan Sel pada Sel Kanser Kolon Manusia)

\author{
Tan Min Jien, Siti Nur Parvin Ab Hamid, Nur Fariesha Md Hashim, Nurdin ARmania, Hasni IdAYu SAidi \\ \& NORAINA MUHAMAD ZAKUAN*
}

\begin{abstract}
Colon cancer is the second leading cause of cancer death among males and females. Survival in colorectal cancer patients is poor and greatly affected by its metastasis. Zerumbone (ZER) is an active compound isolated from the essential volatile oil of an edible ginger plant, Zingiber zerumbet. It is known to exhibit anticancer properties which able to inhibit cancer cell proliferation and induce apoptosis in colon cancer. These findings led us to investigate the ability of ZER to inhibit cell migration in colon cancer cell line. From the MTT results, the IC ${ }_{50}$ values for HCT116 cells treated with ZER were $8.9 \pm 0.3,18.0 \pm 1.2$, and $21.3 \pm 3.5 \mu \mathrm{g} / \mathrm{mL}$ at 24,48 , and $72 \mathrm{~h}$ of incubation, respectively. The results show that the $I C_{50}$ was significantly increased $(p<0.05)$ in a time-dependent manner. The treatment of ZER at higher concentration (6 and $9 \mu \mathrm{g} / \mathrm{mL}$ ) inhibited the migration of HCT116 cells at 1.5-fold higher compared to that of the untreated cells which reduced in the scratch gap. The characteristic of apoptosis such as cell shrinkage, membrane blabbing, and detachment of cells were observed on HCT116 cells treated with ZER, suggesting that the mode cell death induced by ZER on HCT116 cells might be due to apoptosis. Hence, it is concluded that ZER exhibits cytotoxic effects and inhibits cell migration in colon cancer cells.
\end{abstract}

Keywords: Colon cancer; metastasis; migration; Zerumbone

\section{ABSTRAK}

Kanser kolon merupakan penyebab kematian kanser kedua dalam kalangan lelaki dan wanita. Jangka hayat pesakit kanser kolorektal adalah rendah dan sangat terjejas disebabkan oleh metastasis. Zerumbon (ZER) adalah sebatian aktifyang dipencil daripada minyak pati halia yang boleh dimakan, Zingiber zerumbet. Ia dipercayai mempunyai sifat antikanser yang dapat merencat percambahan sel kanser dan mengaruh apoptosis. Penemuan ini membawa kami untuk mengkaji keupayaan ZER untuk merencat penghijrahan sel kanser kolon. Daripada hasil asai MTT, nilai IC untuk sel HCT116 yang dirawat dengan ZER adalah $8.9 \pm 0.3 \mu \mathrm{g} / \mathrm{mL}$ (24 jam), $18.0 \pm 1.2 \mu \mathrm{g} / \mathrm{mL}$ (48 jam) dan 21.3 $\pm 3.5 \mu \mathrm{g} / \mathrm{mL}$ (72 jam). Keputusan ini menunjukkan bahawa $I C_{50}$ meningkat dengan ketara $(p<0.05)$ bergantung dengan masa. Rawatan ZER pada kepekatan yang lebih tinggi (6 dan $9 \mu \mathrm{g} / \mathrm{mL}$ ) merencat penghijrahan sel HCT116 pada tahap 1.5 kali lebih tinggi berbanding dengan sel yang tidak dirawat yang mana saiz ruang lebih mengecil. Ciri-ciri apoptosis seperti pengecutan sel, pembleban membran dan penanggalan sel diperhatikan pada sel HCT116 yang dirawat dengan ZER, menunjukkan bahawa mod kematian terhadap sel HCT116 yang dirawat dengan ZER mungkin disebabkan oleh apoptosis. Oleh itu, disimpulkan bahawa ZER menunjukkan kesan sitotoksik dan merencat penghijrahan sel kanser kolon.

Kata kunci: Kanser kolon; metastasis; penghijrahan; Zerumbon

\section{INTRODUCTION}

In recent years, colon cancer emerges as the second major cause of cancer-associated mortality in cancer patients with 881,000 deaths $(9.2 \%)$ was estimated to occur in 2018 globally (Bray et al. 2018). In Malaysia, colon cancer is the second most common cancer incidence with approximately $13,693(13.2 \%)$ of cancer patients were diagnosed with colon cancer in 2007-2011 (Manan et al. 2016).
Cancer metastasis is the major cause of fatality which occurs in approximately $60 \%$ of colon cancer patients (Siegel et al. 2017). Although the 5-year survival rate for early stage colon cancer patients is up to $90 \%$, the 5 -year survival rate for metastatic state greatly reduced to $13.9 \%$ of patients (Vassos \& Piso 2018). In colon cancer, liver is the most common site of metastasis (Alhumaid et al. 2018). It has been reported that approximately $30 \%$ of all colon cancer patients have liver metastases which 
accounted for two-third of the deaths (Abdalla et al. 2006).

The current available modalities for metastatic colon cancer treatment include surgical resection (Alhumaid et al. 2018) and chemotherapy such as fluorouracil (addition with oxaliplatin and irinotecan) (Cheng et al. 2013). However, the management and treatment of metastasis cancer are still a major challenge because of the lack of understanding on its molecular pathway (Alhumaid et al. 2018).

Despite the availability of many current improved therapies, this study focuses on the utilisation of natural product-derived active compounds, i.e. Zerumbone (ZER) to treat metastasis cancer. ZER is a cyclic sesquiterpene from the rhizomes of an edible ginger plant, Zingiber zerumbet (L.) Smith (originated from Southeast Asia) (Deorukhkar et al. 2015), well known for its potential anticancer properties.

Several studies have proven that ZER inhibits cell proliferation and induces apoptosis in many cancer cells including human colon cancer cell. A recent study shows that ZER can exert anti-metastatic effects via inhibition of FAk/PI3k/NF-kB-uPA signaling pathway (Hosseini et al. 2019), reduce the proliferation of colon cancer cells (HCT116) by inhibiting the tumour necrosis factor alpha (TNF-alpha) (Singh et al. 2018) and enhancing the TNF-related apoptosis-inducing ligand (TRAIL)-induced apoptosis through the up-regulation of TRAIL death receptor DR4 and DR5 (Yodkeeree et al. 2009). Han et al. (2014) also reported that ZER can suppress interleukin$1 \beta$ (IL-1 $\beta$ )-induced cell migration and invasion in human triple-negative breast cancer cells suggesting that ZER could be used to inhibit cell migration and invasion in cancer cells.

In reviewing the literature, there is still insufficient study on the effects of ZER in inhibiting cell migration and invasion towards colon cancer cells. Hence, this study aims to determine the effects of ZER on cell migration and invasion in colon cancer cell lines (HCT116).

\section{MATERIALS AND METHODS}

\section{REAGENTS}

Minimal essential medium with Earle's balanced salts (MEM/EBSS) and fetal bovine serum (FBS) were purchased from GE Healthcare Life Sciences HyClone ${ }^{\mathrm{TM}}$ (Utah, USA), Roswell Park Memorial Institute medium (RPMI-1640) was purchased from Nacalai Tesque Inc. (Kyoto, Japan), dimethyl sulfoxide (DMSO) was purchased from Fisher BioReagents ${ }^{\mathrm{TM}}$ (Massachusetts, USA), $0.5 \%$ Trypsin-EDTA $(10 \times)$ was purchased from Gibco ${ }^{\circledR}$ (Loughborough, USA), penicillin-streptomycin solution $(100 \times)$ was purchased from BBI Life Sciences (Shanghai, China), trypan blue solution $(0.4 \%)$ was purchased from ScienCell ${ }^{\mathrm{TM}}$ Research Laboratories (Carlsbad, USA), 3-(4,5-dimethythiazol2-yl)-2,5-diphenyl tetrazolium bromide (MTT) was purchased from Sigma
Aldrich ${ }^{\circledR}$ (St. Louis, USA), and phosphate-buffered saline tablet was purchased from VWR ${ }^{\circledR}$ Life Science AMRESCO (Ohio, USA).

\section{ZERUMBONE (ZER)}

ZER compound in crystal form (99\% purity) was kindly given by Assoc. Prof. Dr. Enoch Kumar Perimal from Department of Biomedical Science, Faculty of Medicine and Health Sciences, Universiti Putra Malaysia (UPM). The ZER compound was prepared as previously described by Sulaiman et al. (2009), by slicing fresh rhizome of $Z$. zerumbet into pieces of $0.5-1 \mathrm{~mm}$ using a food processor. Then, essential oil from the plant was obtained through hydrodistillation. Hexane was used to enhance the extraction of essential oil. Pure ZER was obtained from the repetitive recrystallisation of the crude hydrodistillate. The identity and purity of ZER were confirmed by nuclear magnetic resonance (NMR) spectrometry and highperformance liquid chromatography (HPLC).

\section{CELL LINE}

Human colon carcinoma cells (HCT116) and mouse embryonic fibroblast cells (NIH/3T3) were purchased from American Type Culture Collection (ATCC $®$ ) (ATCC accession no. HCT116 (CCL-247TM) and NIH/3T3 (CRL$1658^{\mathrm{TM}}$ ), Manassas, USA). HCT116 and NIH/3T3 were cultured in MEM/EBSS and RPMI-1640, respectively, with $10 \%$ of FBS and $1 \%$ of penicillin-streptomycin solution $(10 \times)$. The cells were grown in $\mathrm{T} 75$ tissue culture flask and incubated at $37{ }^{\circ} \mathrm{C}$ and $5 \% \mathrm{CO}_{2}$ incubator.

\section{CYTOTOXICITY ASSAY}

The analysis of cell viability was carried out by MTT cell-proliferation assay as previously described by Tolosa et al. (2015). The MTT assay is a tetrazolium salt reduction assay to assess cell metabolic activity. The cells (HCT116 and NIH/3T3) (1 $10^{4}$ cells/well) were seeded in a 96well plate and incubated for $24 \mathrm{~h}$ to allow the cells to attach to the plate. After $24 \mathrm{~h}$, the medium was removed and the cells were treated with different concentrations of ZER $(6.25,12.5,25,50,75$, and $100 \mu \mathrm{g} / \mathrm{mL})$. The respective concentrations were prepared by diluting the stock solution $(100 \mathrm{mg} / \mathrm{mL}$ in DMSO) with the complete growth medium. The treated cells were incubated for three different time points $(24,48$, and $72 \mathrm{~h})$. The control group (untreated) was also included. After each incubation period, $20 \mu \mathrm{L}$ of MTT solution $(5 \mathrm{mg} / \mathrm{mL})$ was added into each well and incubated for $3 \mathrm{~h}$. Then, the medium containing MTT solution was discarded from the plate. The dark formazan crystals formed in the intact cells were dissolved by adding $100 \mu \mathrm{L}$ of DMSO into each well. The absorbance was measured using a microplate reader (Tecan, infinite ${ }^{\circledR}$ M200, Männedorf, Switzerland) at the wavelength of $570 \mathrm{~nm}$ and reference wavelength of $630 \mathrm{~nm}$. The MTT assay was performed in three replicates of three independent experiments. The 
data obtained were tabulated and the percentage of cell viability for each concentration was calculated using the following formula:

Percentage of cell viability $=\frac{(\text { Absorbance sample })}{(\text { Absorbance control })} \times 100 \%$

\section{MORPHOLOGICAL STUDY}

The HCT116 cells $\left(1 \times 10^{6}\right.$ cells/well $)$ were seeded into a 6-well plate and incubated for $24 \mathrm{~h}$ in the incubator at $37{ }^{\circ} \mathrm{C}$ with $5 \%$ of $\mathrm{CO}_{2}$. Then, the cells were treated with three different selected concentrations $(3,6$, and $9 \mu \mathrm{g} /$ $\mathrm{mL}$ ) of ZER for $24 \mathrm{~h}$. The control group (untreated) was also included. After $24 \mathrm{~h}$, the morphological changes for each concentration were observed under the inverted light microscope (Olympus Research Microscope, $\mathrm{CH} 20 \mathrm{i}$ (Binocular Version), Tokyo, Japan) and compared to the control group.

\section{SCRATCH ASSAY}

The HCT116 cells $\left(1 \times 10^{6}\right.$ cells/well $)$ were seeded on a 6-well plate and incubated at $37{ }^{\circ} \mathrm{C}$ with $5 \%$ of $\mathrm{CO}_{2}$ incubator for $24 \mathrm{~h}$. After the cells attached and formed a confluent monolayer, a scratch was made using a sterile yellow pipette tip $(200 \mu \mathrm{L}$ pipette tip). The cells were treated with three different selected concentrations (3, 6 , and $9 \mu \mathrm{g} / \mathrm{mL})$ of ZER for $24 \mathrm{~h}$. The pictures of initial wound gap at 0 and after $24 \mathrm{~h}$ were taken under the inverted light microscope (Olympus Research Microscope, CH20i (Binocular Version), Tokyo, Japan). The gap difference for each concentration was measured and analysed using ImageJ software (Bethesda, USA).

\section{STATISTICAL ANALYSIS}

IBM Statistical Package for the Social Sciences (SPSS) Statistics 24 software (New York, USA) was used to perform the statistical analysis. The results were presented as mean \pm SEM (standard error of mean) of the mean of three independent experiments. The oneway analysis of variance (ANOVA) was used to analyse the results, followed by Tukey or Dunnett's multiple comparison tests to determine the significant differences between the means. A $p$ value of less than $0.05(p<0.05)$ is considered to have significance.

\section{RESULTS AND DISCUSSION}

\section{ZER INDUCED THE CYTOTOXICITY OF HUMAN COLON CANCER HCT116 CELLS}

In the present study, the MTT assay was performed to evaluate the cytotoxicity of ZER on human colon cancer cells (HCT116). This assay assesses the viability of cells based on the reduction of a tetrazolium component (MTT) into an insoluble formazan product by the mitochondria of viable cells (Bahuguna et al.
2017). This method is quantitative and offers a sensitive detection of cell proliferation as it measures the growth rate of cells by virtue of a linear relationship between cell activity and absorbance (Mahajan et al. 2012).

The treatment with ZER at higher concentrations $(25-100 \mu \mathrm{g} / \mathrm{mL})$ significantly $(p<0.05)$ reduced the cells viability of HCT116 cells (Figure 1(A)) compared to the untreated cells. The $\mathrm{IC}_{50}$ value of HCT 116 cells treated with ZER at 24, 48, and $72 \mathrm{~h}$ of incubation was 8.9, 18.0, and $21.3 \mu \mathrm{g} / \mathrm{mL}$, respectively (Figure $1(\mathrm{~B})$ ). The results show that the $\mathrm{IC}_{50}$ values were significantly increased in time-dependent manner, whereby the HCT116 cells treated with ZER at $24 \mathrm{~h}$ exhibited the lowest $\mathrm{IC}_{50}$ value compared to those of at 48 and $72 \mathrm{~h}$ of incubation at $p$ $<0.05$. Hence, three different selected concentrations of ZER were selected from the $\mathrm{IC}_{50}$ values at $24 \mathrm{~h}$ of incubation for further analysis of cell morphology and scratch assay.

To evaluate the cytotoxic effect of ZER on noncancerous cells, the MTT assay was also performed on mouse embryonic fibroblast cells (NIH/3T3). The NIH/3T3 cell was selected because it is the most commonly used cell for toxicity study (Rejmontová et al. 2016). The treatment of ZER at higher concentrations $(12.5-100 \mu \mathrm{g} / \mathrm{mL})$ significantly $(p<0.05)$ reduced the cell viability of $\mathrm{NIH} / 3 \mathrm{~T} 3$ cell at three different incubation time compared to those of the untreated cells (Figure 2(A)). However, the NIH/3T3 cells treated with ZER at the concentration of $6.25 \mu \mathrm{g} / \mathrm{mL}$ shows $80 \%$ of cell viability. It is suggested that ZER significantly reduced cell proliferation in time-dependent manner. The result of $\mathrm{IC}_{50}$ value of NIH/3T3 cells treated with ZER at 24,48 , and $72 \mathrm{~h}$ of incubation was $37.5,15.3$, and $15.0 \mu \mathrm{g} / \mathrm{mL}$, respectively (Figure 2(B)). The $\mathrm{IC}_{50}$ values of NIH/3T3 cells treated with ZER were significantly reduced in a time-dependent manner, while the NIH/3T3 cells treated with ZER at $24 \mathrm{~h}$ of incubation exhibited the highest $\mathrm{IC}_{50}$ value at $p<0.05$.

Based on the results of cell viability, the $\mathrm{IC}_{50}$ value of HCT116 cells at $24 \mathrm{~h}$ was 4 -fold lower than the $\mathrm{IC}_{50}$ value of NIH/3T3 cells. At the treatment of $9 \mu \mathrm{g} / \mathrm{mL}$ ZER ( $\mathrm{IC}_{50}$ of HCT116 cells; Figure 4$), 74 \%$ of NIH/3T3 cells were found viable. This shows that the ZER at the concentration of $9 \mu \mathrm{g} / \mathrm{mL}$ has cytotoxic effect on HCT116 cells but less cytotoxic on the normal NIH/3T3 cells at $24 \mathrm{~h}$ of incubation. It can be considered that the cytotoxic activity of ZER specifically targets on colon cancer cells as shown by the significant reduction of cell viability in HCT 116 cells at $24 \mathrm{~h}$ of incubation.

It is postulated that ZER might exerts different mechanisms of cell death on the cancer and normal cells. Hoffman et al. (2002) showed that the ability of ZER in inducing high intracellular redox potential lead to inhibition of the cancer growth. However, the treatment of ZER on normal cells shows minimal effect on the growth of normal cells due to the differences in intracellular redox potential. In addition, the suppression of cancer cells by ZER was suggested by the inhibition 
of carcinogen-induced NF- $\kappa \mathrm{B}$ and NF- $\kappa \mathrm{B}$-regulated gene expression (Takada et al. 2005).

The increasing trend of the $\mathrm{IC}_{50}$ value on HCT116 cells in time-dependent manner shows that ZER is effective in inhibiting the growth of cancer cells at shorter incubation period. In contrast, an opposite decreasing trend of the $\mathrm{IC}_{50}$ value on NIH/3T3 cells was observed. Previous studies show that the $\mathrm{IC}_{50}$ value of cancer cells (such as human breast adenocarcinoma, MDAMB-231 and human colorectal cancer cell, COLO205) treated with ZER was decreased in a time-dependent manner (Hosseinpour et al. 2014; Thiyam \& Narasu 2017). It can be hypothesised that the action of ZER on HCT116 cells is less effective as the treatment duration is increased. Therefore, the $\mathrm{IC}_{50}$ value of HCT116 cells at $24 \mathrm{~h}$ of incubation was then selected for further study in morphology and scratch assays, as the $\mathrm{IC}_{50}$ is potent in HCT116 cells but considerably less toxic towards the NIH/3T3 cells.

\section{ZER INHIBITED THE MIGRATION OF HUMAN COLON CANCER HCT116 CELLS}

The in vitro scratch assay was performed to evaluate the capability of ZER to inhibit the migration of HCT116 cells. This assay is a relatively cheap and easy method, where a gap was made by scratching and the movement of cells at the edge of the closing the gap was measured (Liang et al. 2007). Figure 3 shows the gap area of HCT116 cells before and after treated with different concentrations of ZER $(3,6$, and $9 \mu \mathrm{g} / \mathrm{mL})$ for $24 \mathrm{~h}$ of incubation. The treated cells show less migrated cells compared to the untreated cells (Figure 3). Based on the calculated gap area difference, ZER at lower concentration $(3 \mu \mathrm{g} / \mathrm{mL})$ shows the least migrated cells among the other treatment groups compared to that of the untreated cells (Figure 4). However, there was no significant difference $(p>0.05)$ in the percentage of wound closure between the control (untreated cells) and the treated group. This may due to the limitation of the $2 \mathrm{D}$ scratch migration assay model as quantification of the scratch gap was less accurate compared to $3 \mathrm{D}$ migration assay which use porous membrane and quantification of migratory cells. Therefore, 3D migration assay and invasion assay which use extracellular matrix would be very beneficial to be done as future recommendation for this current study.

It is shown that ZER may inhibit the migration of colon cancer cells, which can be postulated by suppressing the cytokines which helps to regulate cell migration in cancer cells. Study done by Hosseini et al. (2019) shown that ZER could suppress cell migration and invasion in colon cancer cells by down-regulated the expression of $\mathrm{NF}-\kappa \mathrm{B}$ and $\mathrm{UPA}$ in FAK/P13K/ AKT pathway. Han et al. (2014) show that ZER can potentially downregulate interleukin-8 (IL-8) and matrix metalloproteinase-3 (MMP-3) that are responsible in the migration and invasion of cancer cells. This also suggests that the effects of ZER in cell migration inhibition through the downregulation of CXCR4 protein expression (Sung et al. 2008) and suppressing the activity of NF- $\kappa \mathrm{B}$ in blocking angiogenesis that is associated with metastasis (Shamoto et al. 2014). A recent study by Wang et al. (2019) shows that ZER treatment at $30 \mu \mathrm{M}(6.5 \mu \mathrm{g} /$ $\mathrm{mL})$ contributed to the reduction of proliferation and migration in esophageal squamous cell carcinomas.

\section{CHARACTERISTICS OF APOPTOSIS IS OBSERVED ON HCT116 CELLS TREATED WITH ZER}

A morphological analysis was performed to evaluate the mode of cell death caused by ZER on HCT116 cells. Figure 5 shows the morphology of HCT116 cells before and after treated with different concentrations of ZER (3, 6 , and $9 \mu \mathrm{g} / \mathrm{mL}$ ) at $24 \mathrm{~h}$ of incubation. From Figure 5(A)$5(\mathrm{C}))$, the cells treated with ZER at higher concentrations (6 and $9 \mu \mathrm{g} / \mathrm{mL}$ ) show apoptotic characteristics such as shrinkage and cells detachment from the plate or floating cells compared to the untreated cells. At $24 \mathrm{~h}$, the cells treated with $9 \mu \mathrm{g} / \mathrm{mL}$ of ZER show membrane blabbing as shown in the arrow in Figure 5(C) (40× magnification).

There are two main modes of cell death which are apoptosis and necrosis. Apoptosis is a natural system used by humans and animals to remove unwanted cells (Liu et al.2018) and regulate cell death in response to stress as well as in normal growth process (Nikoletopoulou et al. 2013). This type of cell death exhibits cytoplasmic shrinkage, condensation of chromatin, plasma membrane blabbing, and presence of apoptotic bodies (Kerr et al. 1972). In contrast to apoptosis, necrosis is a pathological phenomenon resulting from exogenous stress (Liu et al. 2018), with the manifestations of organelles swelling and membrane rupture (Nikoletopoulou et al. 2013). Although these two mechanisms are very much different in nature, apoptosis is preferred as the mode of cell death because necrosis is often associated with inflammation and apoptosis has its molecular repair system (Kanduc et al. 2002). This study is important to investigate the mechanism of cell death on cancer cells by ZER compound ideally through apoptosis. As cancer cells can circumvent apoptosis through the modifications of protein and gene expressions (Fernald \& Kurokawa 2013), it is suggested that the therapeutic effect can promote apoptosis in the cancer cells (Zhang et al. 2012). It is shown that ZER kills HCT116 cells through apoptotic pathway. Yodkeeree et al. (2009) has proven that the treatment with ZER can enhance TRAILinduced apoptosis in HCT116 cells, induced by the upregulation of TRAIL receptors. The mechanism of ZER in apoptosis is through downregulating anti-apoptotic and upregulating apoptotic proteins, to facilitate the permeabilisation of outer mitochondrial membrane and results in the release of cytochrome c (Hosseinpour et al. 2014). 
A

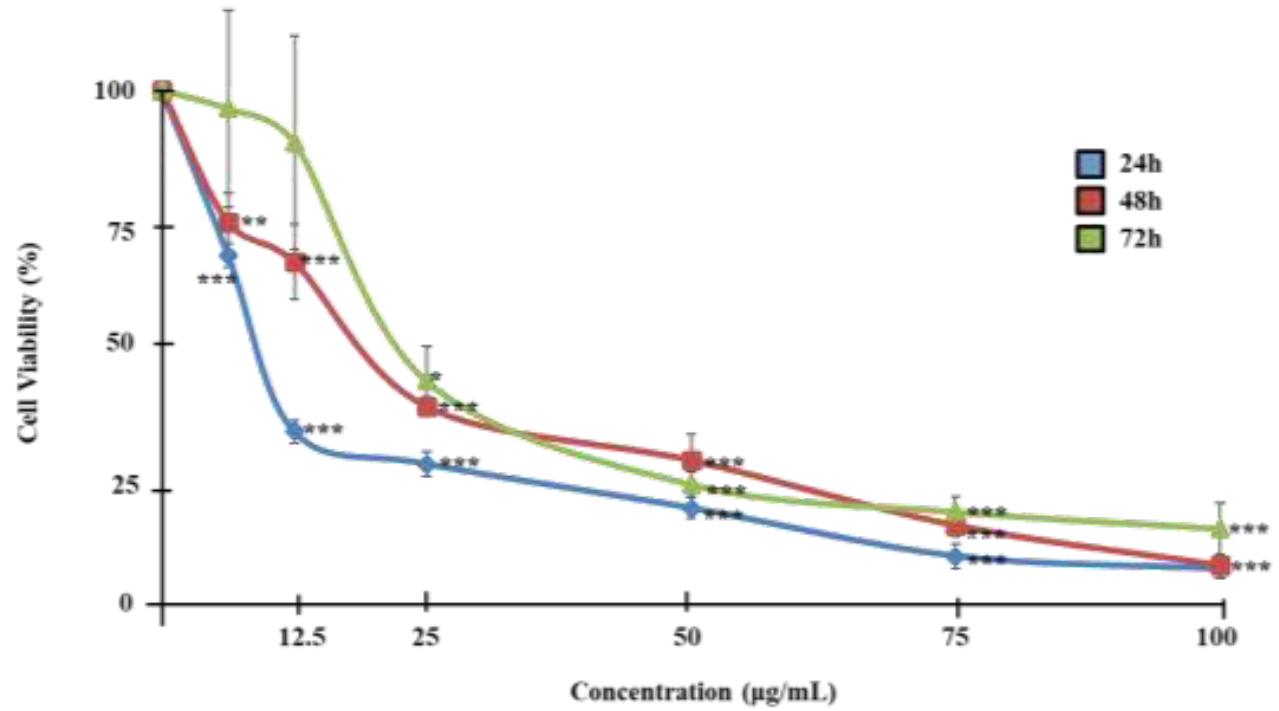

B

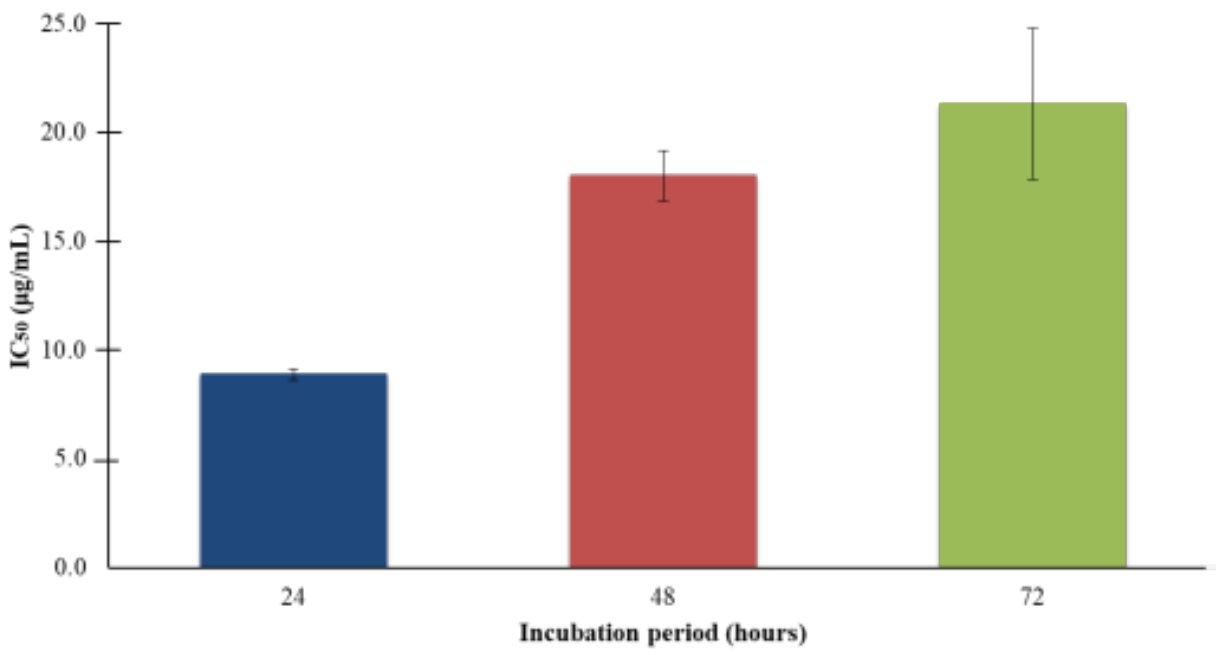

FIGURE 1. Cytotoxicity of ZER on HCT116 cells (A) Percentages of cell viability of HCT 116 cells treated with different concentrations of ZER at 24, 48, and $72 \mathrm{~h}$ of incubation, and (B) The $\mathrm{IC}_{50}$ value of ZER on HCT116 cells at three different incubation periods. Data were expressed as mean \pm SEM of three independent experiments. Results were analysed using One-way ANOVA and Dunnett test. The significant mean difference of p-value less than 0.05, 0.01 and 0.001 is expressed as *,** and $* * *$, respectively, as compared to the control group (untreated cells) 
A

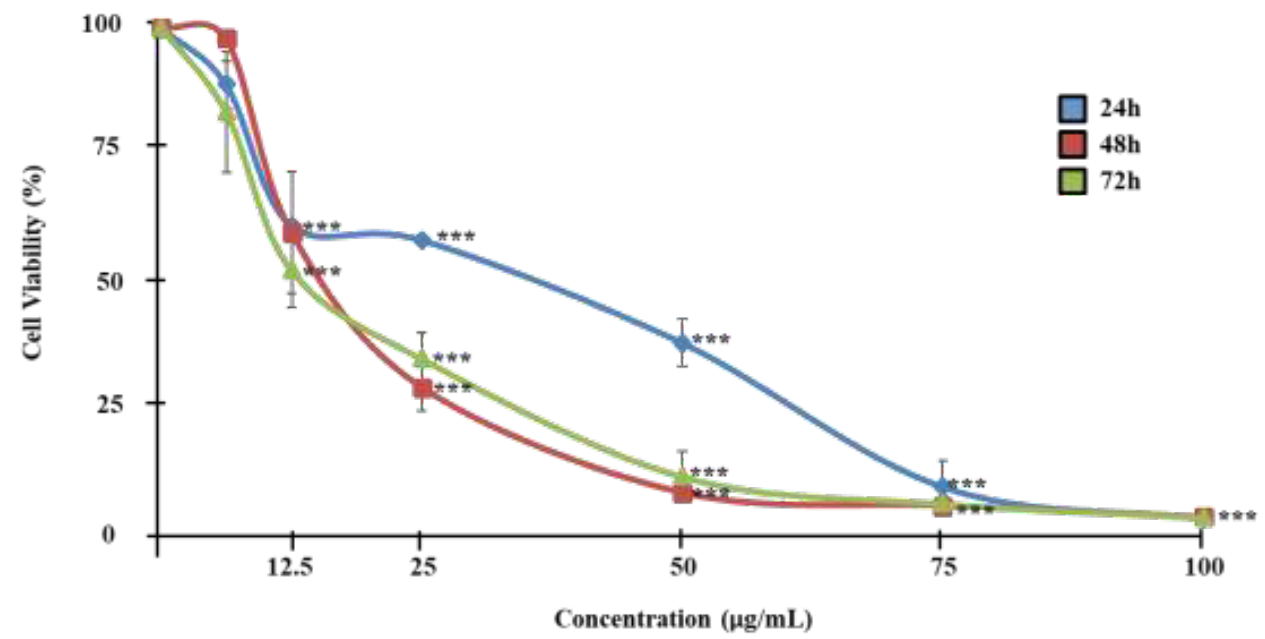

B

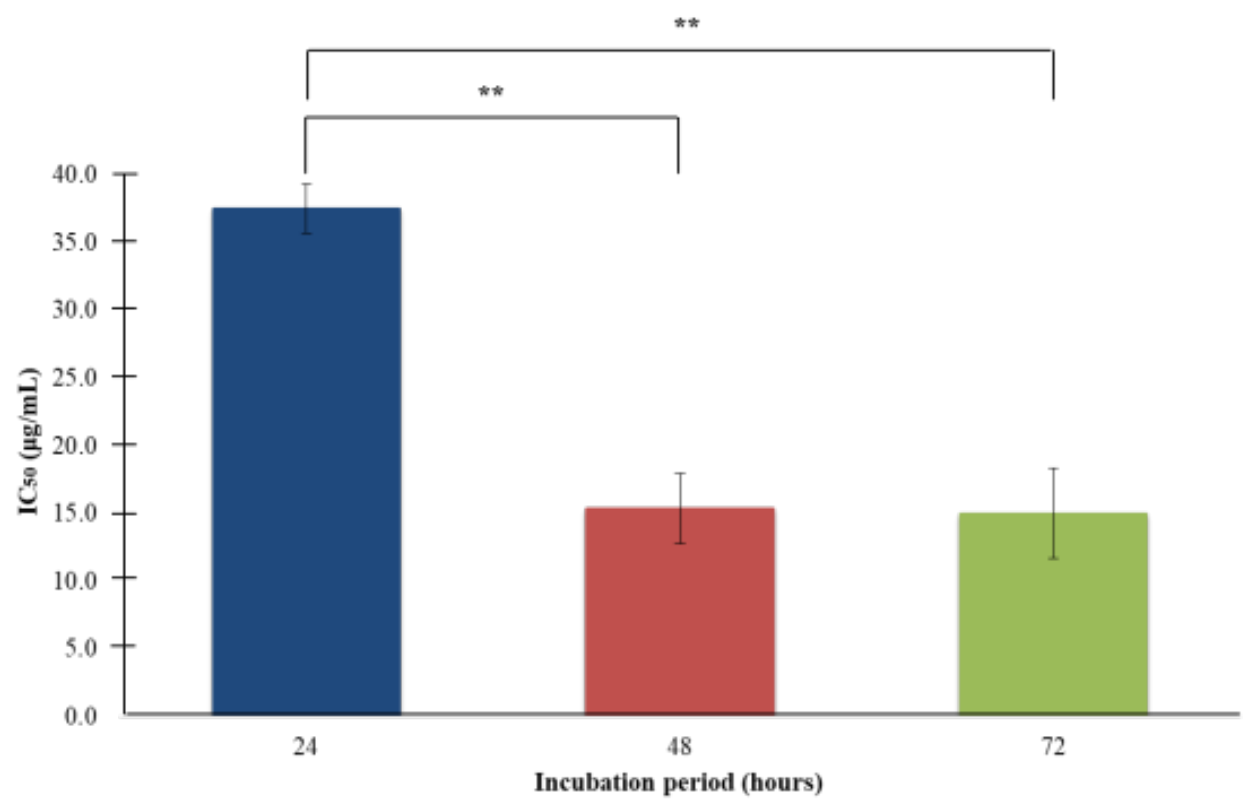

FIGURE 2. Cytotoxicity of ZER on NIH/3T3 cells (A) Percentages of cell viability of NIH/3T3 cells treated with different concentrations of ZER at 24,48 , and $72 \mathrm{~h}$ of incubation, and (B) The $\mathrm{IC}_{50}$ value of ZER on NIH/3T3 cells at three different incubation periods. Data were expressed as mean \pm SEM of three independent experiments. Results were analysed using One-way ANOVA and Dunnett test. The significant mean difference of p-value less than $0.05,0.01$ and 0.001 is expressed as $* * *$ and $* * *$, respectively, as compared to the control group (untreated cells) 


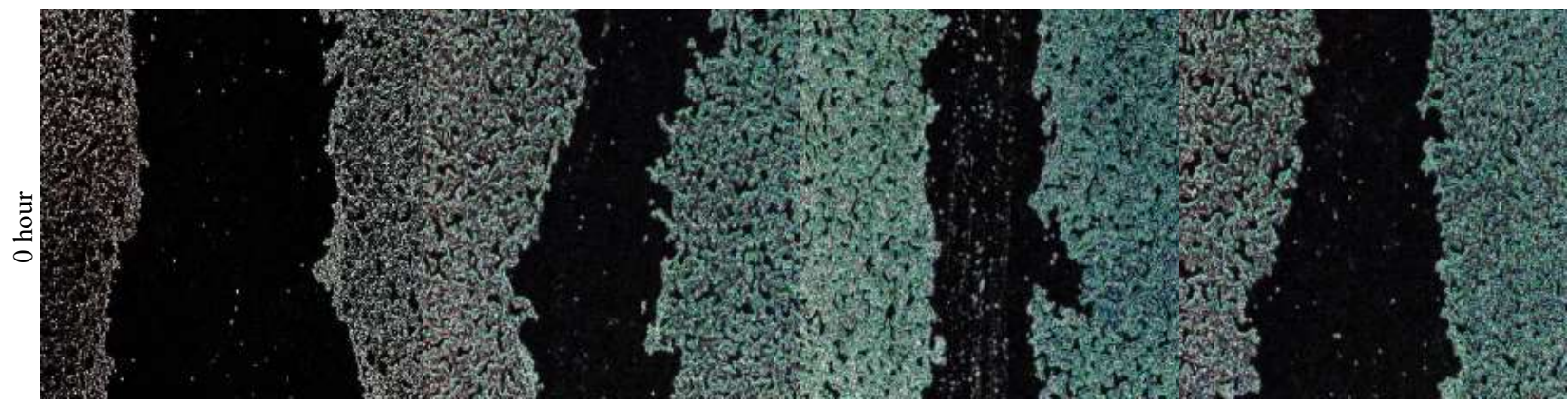

$0 \mu \mathrm{g} / \mathrm{mL}$

$3 \mu \mathrm{g} / \mathrm{mL}$

$6 \mu \mathrm{g} / \mathrm{mL}$

$9 \mu \mathrm{g} / \mathrm{mL}$

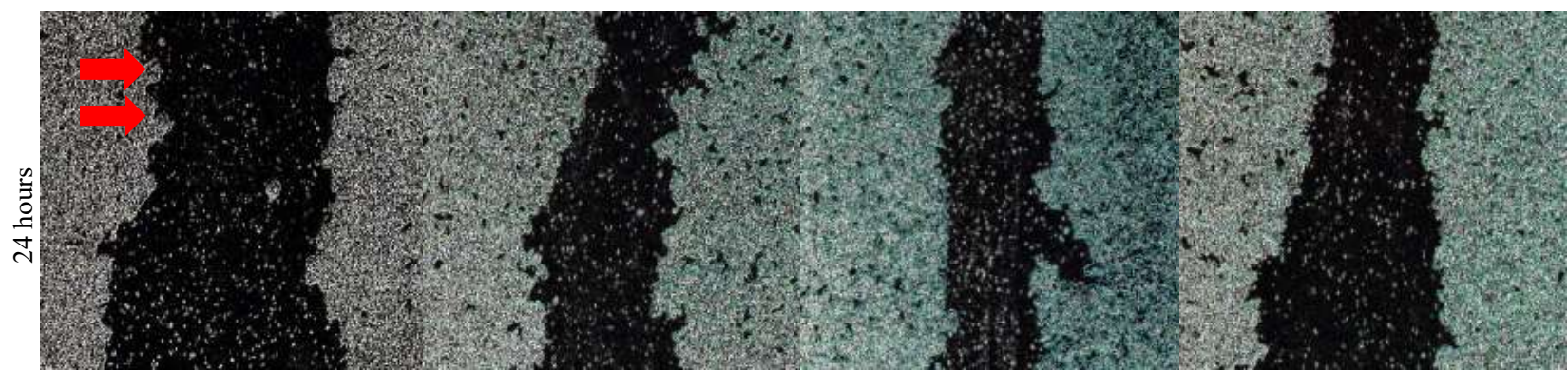

$0 \mu \mathrm{g} / \mathrm{mL}$

$3 \mu \mathrm{g} / \mathrm{mL}$

$6 \mu \mathrm{g} / \mathrm{mL}$

$9 \mu \mathrm{g} / \mathrm{mL}$

FIGURE 3. Scratch of HCT116 cells treated with different concentrations of ZER at 0 and $24 \mathrm{~h}$ incubation time ( $4 \times$ magnification)

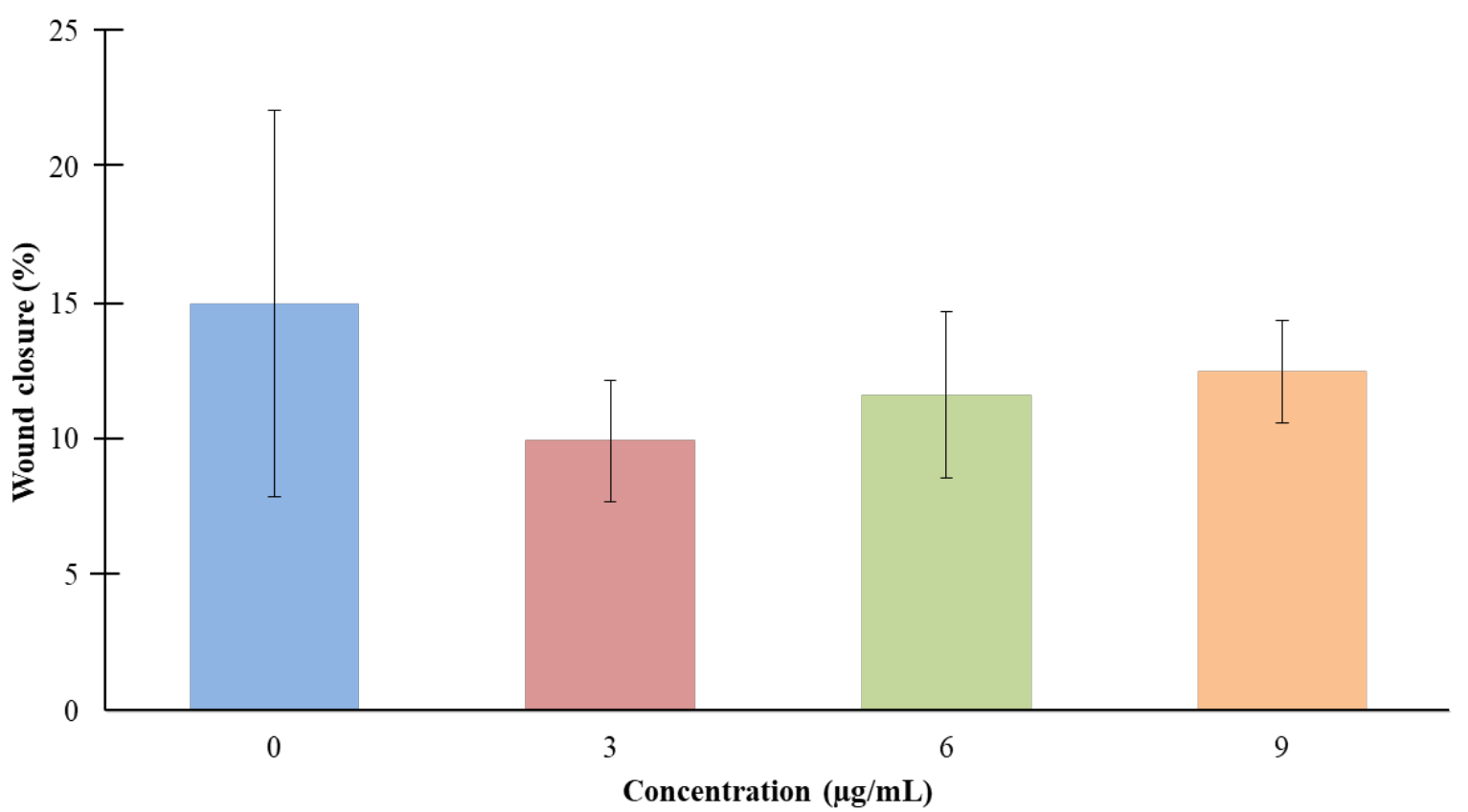

FIGURE 4. Percentage of wound closure of HCT116 cells treated with different concentrations of ZER after $24 \mathrm{~h}$ incubation time in scratch assay. Data were expressed as mean \pm SEM of two independent experiments. Results were analysed using One-way ANOVA and Dunnett test. The significant mean difference of $\mathrm{p}$ value less than $0.05,0.01$ and 0.001 is expressed as *,** and $* * *$, respectively, as compared to the control group (untreated cells) 


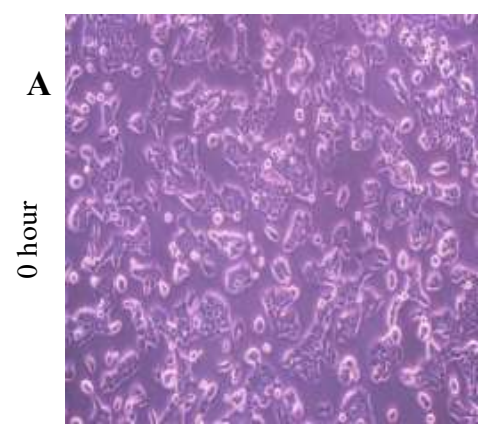

Untreated

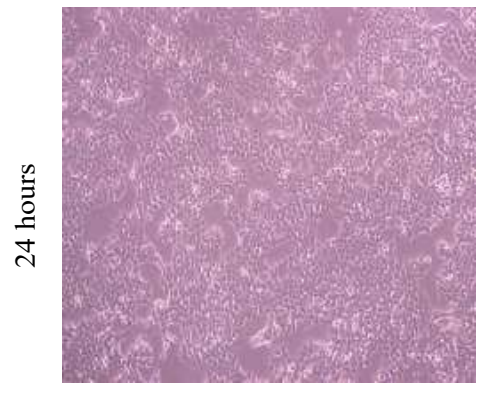

Untreated

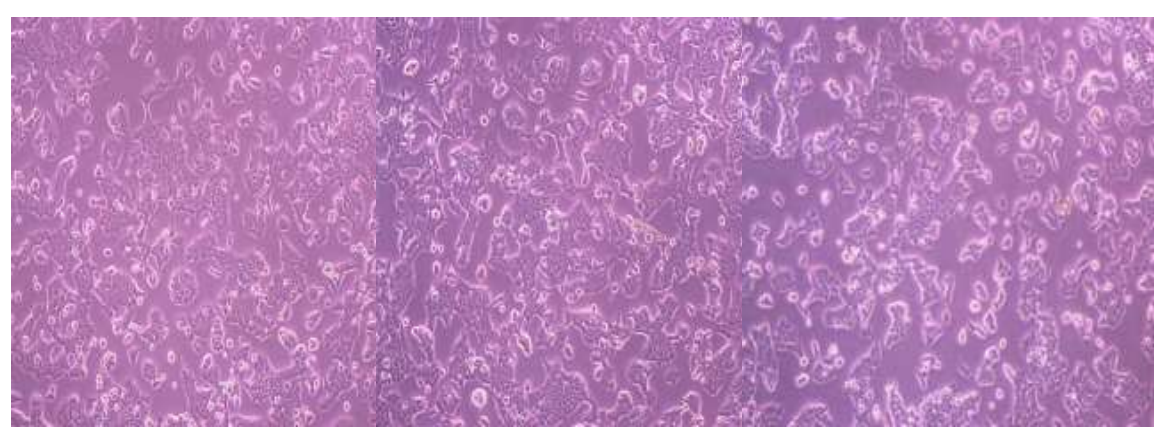

$3 \mu \mathrm{g} / \mathrm{mL}$

$6 \mu \mathrm{g} / \mathrm{mL}$

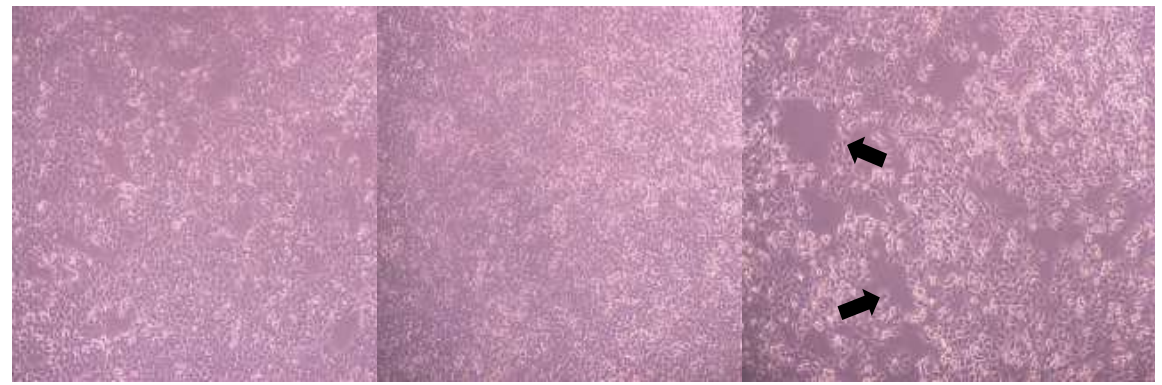

$3 \mu \mathrm{g} / \mathrm{mL}$
$6 \mu \mathrm{g} / \mathrm{mL}$

$9 \mu \mathrm{g} / \mathrm{mL}$

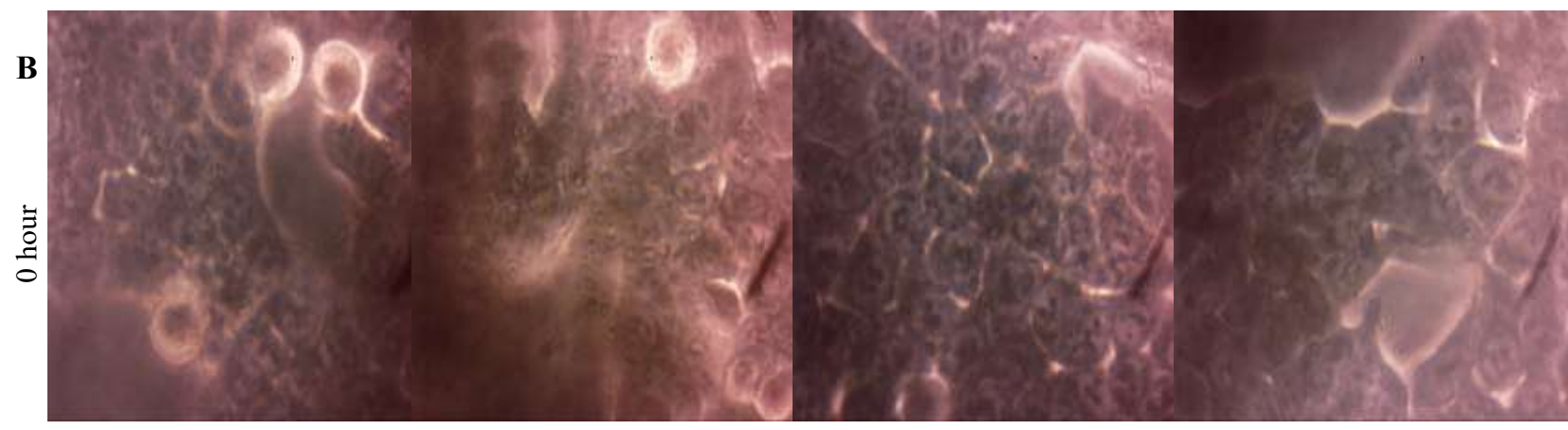

$0 \mu \mathrm{g} / \mathrm{mL}$

$3 \mu \mathrm{g} / \mathrm{mL}$

$6 \mu \mathrm{g} / \mathrm{mL}$

$9 \mu \mathrm{g} / \mathrm{mL}$

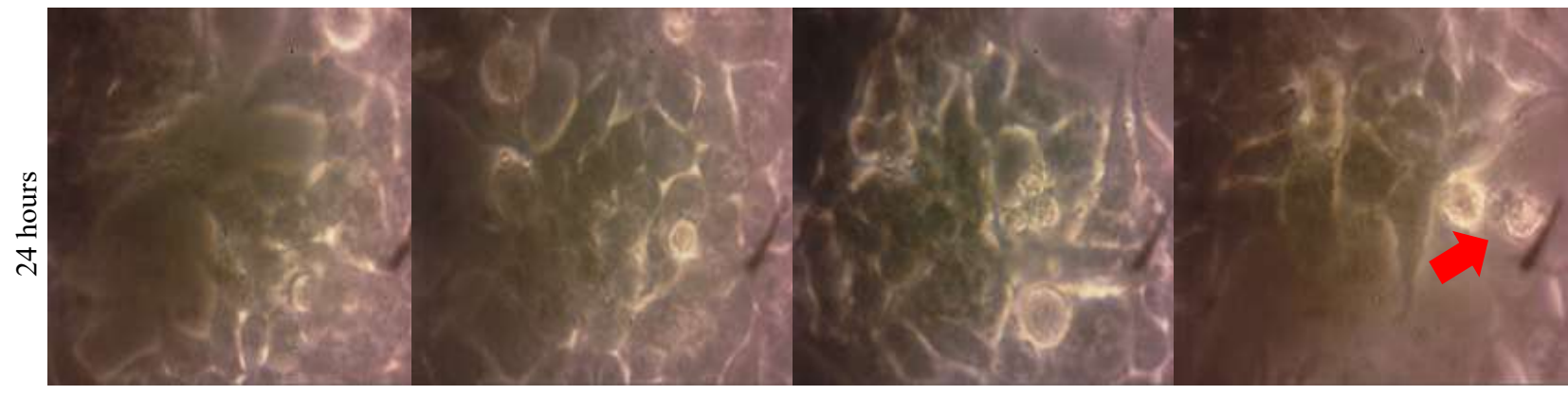

$0 \mu \mathrm{g} / \mathrm{mL}$

$3 \mu \mathrm{g} / \mathrm{mL}$

$6 \mu \mathrm{g} / \mathrm{mL}$

$9 \mu \mathrm{g} / \mathrm{mL}$ 


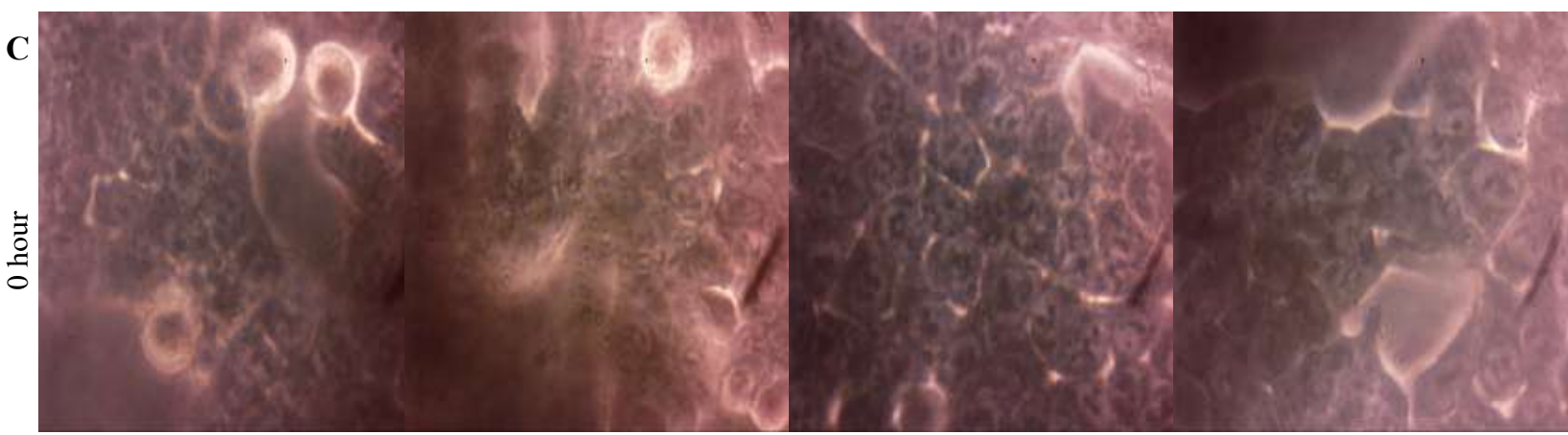

$0 \mu \mathrm{g} / \mathrm{mL}$

$3 \mu \mathrm{g} / \mathrm{mL}$

$6 \mu \mathrm{g} / \mathrm{mL}$

$9 \mu \mathrm{g} / \mathrm{mL}$

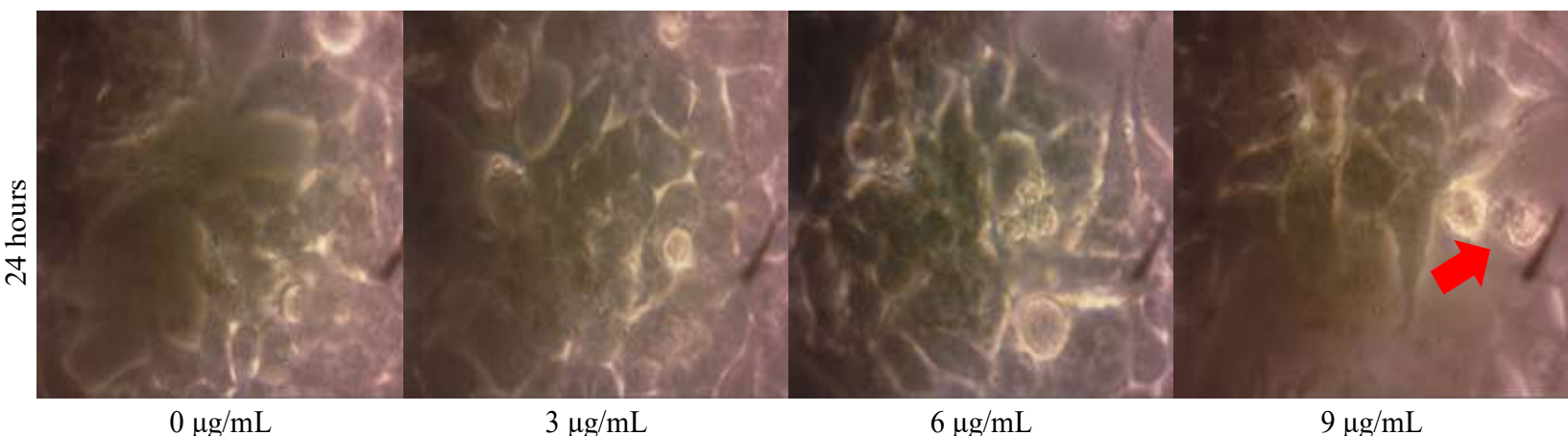

FIGURE 5. Morphology of HCT116 cells treated with different concentrations of ZER at 0 and $24 \mathrm{~h}$ incubation time (A: $10 \times$ magnification; B: $20 \times$ magnification; C: $40 \times$ magnification)

\section{CONCLUSION}

The preliminary findings in this study show that ZER can induce cytotoxicity and inhibits cell migration of human colon carcinoma cells (HCT116). Hence, the result suggests that ZER could be a promising agent to reduce the invasiveness of colon cancer cells. However, further studies on the mechanisms underlying the inhibition of colon cancer cells migration induce by ZER need to be carried out.

\section{ACKNOWLEDGEMENTS}

The authors would like to acknowledge all staff of the Department of Biomedical Sciences, Faculty of Medicine and Health Sciences, Universiti Putra Malaysia for all the assistance and guidance throughout the research project. The authors declare that they have no competing interests.

\section{REFERENCES}

Abdalla, E.K., Adam, R., Bilchik, A.J., Jaeck, D., Vauthey, J.N. \& Mahvi, D. 2006. Improving resectability of hepatic colorectal metastases: Expert consensus statement. Annals Surgical Oncology 13(10): 1271-1280.

Alhumaid, A., Al Yousef, Z., Bakhsh, H.A., AlGhamdi, S. \& Aziz, M.A. 2018. Emerging paradigms in the treatment of liver metastases in colorectal cancer. Critical Reviews in Oncology/Hematology 132(2018): 39-50.
Bahuguna, A., Khan, I., Bajpai, V.K. \& Kang, S.C. 2017. MTT assay to evaluate the cytotoxic potential of a drug. Bangladesh Journal of Pharmacology 12(2): 115-118.

Bray, F., Ferlay, J., Soerjomataram, I., Siegel, R.L., Torre, L.A. \& Jemal, A. 2018. Global cancer statistics 2018: GLOBOCAN estimates of incidence and mortality worldwide for 36 cancers in 185 countries. CA: A Cancer Journal for Clinicians 68(6): 394-424

Cheng, Y., Yang, H., Chen, G. \& Zhang, Z. 2013. Molecularly targeted drugs for metastatic colorectal cancer. Drug Design, Development and Therapy 7: 1315-1322.

Deorukhkar, A., Ahuja, N., Mercado, A.L., Diagaradjane, P., Raju, U., Patel, N., Mohindra, P., Diep, N., Guha, S. \& Krishnan, S. 2015. Zerumbone increases oxidative stress in a thiol-dependent ROS-independent manner to increase DNA damage and sensitize colorectal cancer cells to radiation. Cancer Medicine 4(2): 278-292.

Fernald, K. \& Kurokawa, M. 2013. Evading apoptosis in cancer. Trends in Cell Biology 23(12): 620-633.

Han, J., Bae, S.Y., Oh, S.J., Lee, J., Lee, J.H., Lee, H.C., Lee, S.K., Kil, W.H., Kim, S.W., Nam, S.J., Kim, S. \& Lee, J.E. 2014. Zerumbone suppresses IL-1 $\beta$-induced cell migration and invasion by inhibiting IL- 8 and MMP-3 expression in human triple-negative breast cancer cells. Phytotherapy Research 28(11): 1654-1660.

Hoffman, A., Spetner, L.M. \& Burke, M. 2002. Redox-regulated mechanism may account for zerumbone's ability to suppress cancer-cell proliferation. Carcinogenesis 23(11): 1961-1962. 
Hosseini, N., Khoshnazar, A., Saidijam, M., Azizi Jalilian, F., Najafi, R., Mahdavinezhad, A., Ezati, R., Sotanian, A. \& Amimi, R. 2019. Zerumbone suppress human colorectal cancer invasion and metastasis via modulation of FAk/PI3k/ NFKB-uPA pathway. Nutrition and Cancer 71(1): 159-171.

Hosseinpour, M., Abdul, A.B., Rahman, H.S., Rasedee, A., Yeap, S.K., Ahmadi, N., Othman, H.H. \& Chartrand, M.S. 2014. Comparison of apoptotic inducing effect of zerumbone and zerumbone-loaded nanostructured lipid carrier on human mammary adenocarcinoma MDA-MB-231 cell line. Journal of Nanomaterials 2014: 1-10.

Kerr, J.F.R., Wyllie, A.H. \& Currie, A.R. 1972. Apoptosis: A basic biological phenomenon with wide-ranging implications in tissue kinetics. British Journal of Cancer 26(4): 239-257.

Kanduc, D., Mittelman, A., Serpico, R., Sinigaglia, E., Sinha, A.A., Natale, C., Santacroce, R., Di Corcia, M.G., Lucchese, A., Dini, L., Pani, P., Santacroce, S., Simone, S., Bucci, R. \& Farber, E. 2002. Cell death: Apoptosis versus necrosis (review). International Journal of Oncology 21(1): 165-170.

Liang, C.C., Park, A.Y. \& Guan, J.L. 2007. In vitro scratch assay: A convenient and inexpensive method for analysis of cell migration in vitro. Nature Protocols 2(2): 329-333.

Liu, X., Yang, W., Guan, Z., Yu, W., Fan, B., Xu, N. \& Liao, D.J. 2018. There are only four basic modes of cell death, although there are many ad-hoc variants adapted to different situations. Cell \& Bioscience 8(1): 1-12.

Mahajan, S.D., Law, W.D., Aalinkeel, R., Reynolds, J., Nair, B.B., Yong, K.T., Roy, I., Prasad, P.N. \& Schwartz, S.A. 2012. Nanoparticle-mediated targeted delivery of antiretrovirals to the brain. Methods in Enzymology 509: 41-60.

Manan, A.A., Tamin, N.S.I., Abdullah, N.S., Abidin, A.Z. \& Wahab, M. 2016. Malaysian National Cancer Registry Report 2007-2011. Putrajaya: Ministry of Health, Malaysia. pp. 1-228.

Nikoletopoulou, V., Markaki, M., Palikaras, K. \& Tavernarakis, N. 2013. Crosstalk between apoptosis, necrosis and autophagy. Biochimica et Biophysica Acta 1833(12): 34483459.

Rejmontová, P., Capáková, Z., Mikušová, N., Maráková, N., Kašpárková, V., Lehocký, M. \& Humpolíček, P. 2016. Adhesion, proliferation and migration of NIH/3T3 cells on modified polyaniline surfaces. International Journal of Molecular Sciences 17(9): 1439.

Shamoto, T., Matsuo, Y., Shibata, T., Tsuboi, K., Nagasaki, T., Takahashi, H., Funahashi, H., Okada, Y. \& Takeyama, H. 2014. Zerumbone inhibits angiogenesis by blocking NF- $\mathrm{KB}$ activity in pancreatic cancer. Pancreas 43(3): 396-404.

Siegel, R.L., Miller, K.D., Fedewa, S.A., Ahnen, D.J., Meester, R.G.S., Barzi, A. \& Jemal, A. 2017. Colorectal cancer statistics, 2017. CA: A Cancer Journal for Clinicians 67(3): 177-193.

Singh, S.P., Nongalleima, K., Singh, N.I., Doley, P., Singh, C.B., Singh, T.R. \& Sahoo, D. 2018. Zerumbone reduces proliferation of HCT116 colon cancer cells by inhibition of TNF-alpha. Scientific Reports 8(1): Article ID. 4090.

Sulaiman, M.R., Perimal, E.K., Zakaria, Z.A., Mokhtar, F., Akhtar, M.N., Lajis, N.H. \& Israf, D.A. 2009. Preliminary analysis of the antinociceptive activity of zerumbone. Fitoterapia 80(4): 230-232.

Sung, B., Jhurani, S., Ahn, K.S., Mastuo, Y., Yi, T., Guha, S., Liu, M. \& Aggarwal, B.B. 2008. Zerumbone downregulates chemokine receptor $\mathrm{CXCR} 4$ expression leading to inhibition of CXCL12-induced invasion of breast and pancreatic tumor cells. Cancer Research 68(21): 8938-8944.

Takada, Y., Murakami, A. \& Aggarwal, B.B. 2005. Zerumbone abolishes NF- $\kappa \mathrm{B}$ and $\mathrm{I} \kappa \mathrm{B}$ alpha kinase activation leading to suppression of antiapoptotic and metastatic gene expression, upregulation of apoptosis, and downregulation of invasion. Oncogene 24(46): 6957-6969.

Thiyam, R. \& Narasu, M.L. 2017. Evaluation of cytotoxic and genotoxic effects of Zerumbone on colon adenocarcinoma COLO205 cells and human lymphocytes. International Journal of Pharmacy and Pharmaceutical Sciences 9(11): 92-96.

Tolosa, L., Donato, M.T. \& Gómez-Lechón, M.J. 2015. General cytotoxicity assessment by means of the MTT assay. Methods in Molecular Biology 1250: 333-348.

Vassos, N. \& Piso, P. 2018. Metastatic colorectal cancer to the peritoneum: Current treatment options. Current Treatment Options in Oncology 19(10): 1-18.

Wang, M., Niu, J., Gao, L., Gao, Y. \& Gao, S. 2019. Zerumbone inhibits migration in ESCC via promoting Rac1 ubiquitination. Biomedicine and Pharmacotherapy 109: 2447-2455.

Yodkeeree, S., Sung, B., Limtrakul, P. \& Aggarwal, B.B. 2009. Zerumbone enhances TRAIL-induced apoptosis through the induction of death receptors in human colon cancer cells: Evidence for an essential role of reactive oxygen species. Cancer Research 69(16): 6581-6589.

Zhang, S., Liu, Q., Liu, Y., Qiao, H. \& Liu, Y. 2012. Zerumbone, a Southeast Asian ginger sesquiterpene, induced apoptosis of pancreatic carcinoma cells through $\mathrm{p} 53$ signaling pathway. Evidence-based Complementary and Alternative Medicine 2012: 1-8.

Tan Min Jien, Siti Nur Parvin Ab Hamid, Nur Fariesha Md Hashim, Nurdin Armania, Hasni Idayu Saidi \& Noraina Muhamad Zakuan*

Department of Biomedical Sciences

Faculty of Medicine and Health Sciences

Universiti Putra Malaysia

43400 UPM Serdang, Selangor Darul Ehsan

Malaysia

Nurdin Armania

Department of UPM-MAKNA Cancer Research (CANRES)

Institute of Bioscience

Universiti Putra Malaysia

43400 UPM Serdang, Selangor Darul Ehsan

Malaysia

*Corresponding author; email: noraina@upm.edu.my

Received: 9 December 2019

Accepted: 26 February 2020 
TABLE S1. Percentage of cell viability of HCT116 cells treated with different concentrations of ZER at three different incubation periods $(24,48$, and $72 \mathrm{~h})$

\begin{tabular}{|c|c|c|c|}
\hline \multirow{2}{*}{ Concentration $(\mu \mathrm{g} / \mathrm{mL})$} & \multicolumn{3}{|c|}{ Cell viability (\%) } \\
\hline & $24 \mathrm{~h}$ & $48 \mathrm{~h}$ & $72 \mathrm{~h}$ \\
\hline 0 & $100.00 \pm 0.00$ & $100.00 \pm 0.00$ & $100.00 \pm 0.00$ \\
\hline 6.25 & $67.92 \pm 2.26^{* * *}$ & $74.40 \pm 5.59^{* *}$ & $96.40 \pm 19.19$ \\
\hline 12.5 & $33.69 \pm 2.26^{* * *}$ & $66.63 \pm 7.35^{* * *}$ & $89.94 \pm 20.70$ \\
\hline 25 & $27.40 \pm 2.32 * * *$ & $38.60 \pm 1.91 * * *$ & $43.53 \pm 6.73 *$ \\
\hline 50 & $18.86 \pm 1.96^{* * *}$ & $28.14 \pm 5.08^{* * *}$ & $23.43 \pm 2.42 * * *$ \\
\hline 75 & $9.51 \pm 2.47 * * *$ & $15.51 \pm 2.06^{* * *}$ & $18.11 \pm 3.03^{* * *}$ \\
\hline 100 & $7.06 \pm 1.82 * * *$ & $7.74 \pm 0.11^{* * *}$ & $14.83 \pm 5.06^{* * *}$ \\
\hline
\end{tabular}

Data were expressed as mean \pm SEM of three independent experiments. Results were analysed using One-way ANOVA and Dunnett test. The significant mean difference of $p$-value less than $0.05,0.01$ and 0.001 is expressed as *,** and $* * *$, respectively, as compared to the control group (untreated cells)

TABLE S2. $\mathrm{IC}_{50}$ values of ZER treated on HCT116 cells at three different incubation periods $(24,48$, and $72 \mathrm{~h})$

\begin{tabular}{lc}
\hline \multicolumn{1}{c}{ Incubation period (h) } & $\mathrm{IC}_{50}(\mu \mathrm{g} / \mathrm{mL})$ \\
\hline 24 & $8.88 \pm 0.25^{\mathrm{a}}$ \\
48 & $18.00 \pm 1.15^{\mathrm{ab}}$ \\
72 & $21.33 \pm 3.48^{\mathrm{b}}$ \\
\hline
\end{tabular}

Data were expressed as mean \pm SEM of three independent experiments. Results were analysed using One-way ANOVA and Tukey HSD. The significant mean difference between groups (incubation period) of $p$-value less than 0.05 is expressed with different superscript letter ${ }^{\mathrm{a}}$ and ${ }^{\mathrm{b}}$ 
TABLE S3. Percentage of cell viability of NIH/3T3 cells treated with different concentrations of ZER at three different incubation periods $(24,48$, and $72 \mathrm{~h})$

\begin{tabular}{|c|c|c|c|}
\hline \multirow{2}{*}{ Concentration $(\mu \mathrm{g} / \mathrm{mL})$} & \multicolumn{3}{|c|}{ Cell viability (\%) } \\
\hline & $24 \mathrm{~h}$ & $48 \mathrm{~h}$ & $72 \mathrm{~h}$ \\
\hline 0 & $100.00 \pm 0.00$ & $100.00 \pm 0.00$ & $100.00 \pm 0.00$ \\
\hline 6.25 & $88.80 \pm 4.65$ & $97.78 \pm 1.45$ & $83.41 \pm 11.81$ \\
\hline 12.5 & $61.11 \pm 1.06^{* * *}$ & $59.80 \pm 11.89 * * *$ & $52.45 \pm 7.46^{* * *}$ \\
\hline 25 & $58.35 \pm 1.00 * * *$ & $29.44 \pm 4.50 * * *$ & $35.07 \pm 5.13 * * *$ \\
\hline 50 & $38.15 \pm 4.61 * * *$ & $8.78 \pm 1.45^{* * *}$ & $11.96 \pm 5.02 * * *$ \\
\hline 75 & $9.89 \pm 5.15^{* * *}$ & $6.19 \pm 1.15^{* * *}$ & $6.62 \pm 1.41 * * *$ \\
\hline 100 & $3.64 \pm 0.66^{* * *}$ & $3.96 \pm 1.15^{* * *}$ & $3.94 \pm 0.58 * * *$ \\
\hline
\end{tabular}

Data were expressed as mean \pm SEM of three independent experiments. Results were analysed using One-way ANOVA and Dunnett test. The significant mean difference of $p$-value less than $0.05,0.01$ and 0.001 is expressed as $* * *$ and ${ }^{* *}$, respectively, as compared to the control group (untreated cells) 